\title{
Possible Outcomes of Introducing a Majority System for Elections to the Czech Parliament's Chamber of Deputies
}

\author{
MICHAL PINK ${ }^{1}$
}

\begin{abstract}
This paper explores the possibility of introducing a majority electoral system for the Chamber of Deputies in the Cqech Republic, and discusses the virtues and drawbacks of such a system. It recalculates the electoral results from two previous elections using majority electoral systems (first-pastthe-post and two round majority system) to examine how such a change could influence the formation of governmental majorities in the chamber and what the possible consequences for the quality of democracy in the Czech Republic could be. The results show that majority system would likely radically simplify the formation of governments with clear majorities, and hinder emerging populist parties as well as weaken the communist party. On the other hand, the adoption of a majority system would substantially lower barriers to enter the chamber, which could lead to the disintegration of the party system and its increased fragmentation. Combined with the common practice of $C_{z e c h}$ politicians to hold various mandates at different levels of the political system at the same time, this could be a significant risk factor.
\end{abstract}

Keywords: Elections; Czech Politics; Electoral System; First-Past-the-Post; Two Round Majority System

\section{Introduction}

Over the past two decades, scholars have largely come to agree that the characteristics of the system used to elect the lower chamber of Parliament, the Chamber of Deputies, are a weakness of Czech democracy (Šedo 2009a; 2009b; Chytilek et al. 2009; Kubát 2013). ${ }^{2}$ The outcomes of the system since 1996 have

\footnotetext{
${ }^{1}$ Department of Political Science, Faculty of Social Studies, Masaryk University, Joštova 10, 60200 Brno, Czech Republic. E-mail: mpink@seznam.cz. This article is an output of a Czech Science Foundation grant, code GA15-2274S (Quality of Democracy: Czech Republic in Comparative Perspective). I would like to thank Petr Voda for long-term cooperation in preparation of all maps.

2 The Czech Republic is a parliamentary democracy with a bi-cameral parliament, consisting of the Chamber of Deputies and the Senate. It is a clear example of asymmetric bicameralism, with the powers of the Chamber of Deputies stronger and, in many examples (such as legislative process), more decisive compared to those of the Senate. The Czech party system had been characterized
} 
been considered the main source of government instability, due to ambiguously defined majorities in the chamber (Kubát 2013). The government that came to power in 2010 had a clear majority and it seemed that the problem had largely been solved, ${ }^{3}$ yet instead of government stability, disunity emerged in the parliamentary Public Affairs party (Véci verégné, VV), originally a populist party that became a part of the government coalition. The VV party ultimately split into two. The subsequent early election in autumn 2013 produced a government coalition of three parties, and only time will tell whether what originally emerged as a populist movement and is now (as of October 2017) the second most important partner in government, the ANO 2011 movement (hereinafter ANO), will prove to be cohesive ibn the long term, or whether it will meet with a fate similar to that of Public Affairs, which immediately after the 2010 election also served as a pillar of government stability. At the time of writing it seems that discord is not in the offing for ANO, but this cannot be said with great certainty until a more distant future. Until 2010, the electoral system was unable to convert votes into seats in a manner that would secure a clear governmental majority in the chamber, and since 2010 its logic has also led to increased parliamentary presence of populist parties.

When electoral reform was considered at various points over the past two decades, the alternatives proposed were based on (a) the established rules for proportional representation of candidate lists, varying the electoral formula merely by changing the electoral divisor, or constituency size; (b) the idea of awarding an electoral bonus, which was mooted, especially after the 2006 elections ended in a stalemate. With one exception (Kubát 2013), none of the proposals envisaged a more fundamental change by introducing a majority system for the election of the Chamber of Deputies. At a scholarly conference in November 2012 (Balík et al. 2013) such an option was discussed, which led me to develop the idea further.

The conference was organised by the group 'Direct Election of Deputies 2014' (Prímá volba poslancu 2014), which promoted the adoption of a majority electoral system and was supported by the prime minister at the time. The papers published in the conference proceedings evaluate the options for improving the Czech parliamentary regime: the authors agreed that an improvement was needed, but they failed to propose a clear solution. Primarily, the authors investigated the option of introducing a majority electoral system, and besides the proponents of a 'relatively strong' model (i.e. a two-round system), there were also those who focused on the

by low levels of volatility (see Deegan-Krause and Haughton 2010), which began to crumble in 2010. New parties, such as the rightist TOP 09 and the short-lived populist Public Affairs party entered the national political scene, followed by another populist party (ANO) and the far-right populist Úsvit in the early elections in 2013 (for a concise and insightful overview of the party system development in English see Balík and Hloušek 2016).

${ }^{3}$ On 10 August 2010, the newly-appointed government consisting of the ODS, TOP09 and VV won the chamber's confidence on 118 votes, which was significantly above the required minimum (101 votes) and compared well with previous votes of confidence. 
risks of such a system. Some of these authors argued that the potential benefits of the system would not outweigh its risks.

Prior to the 2013 elections, politicians for the Civic Democratic Party (Obcranská demokratická strana; ODS), especially Petr Sokol and the acting chair of the party, Martin Kuba, proposed to introduce a majority system. Since then, the populist parties, Tomio Okamura's Dawn of Direct Democracy (Úsvit prímé demokracie, Dawn) and the populist movement ANO, which entered government after the 2013 elections, have also started publicly advocating the introduction of a majority system. ${ }^{4}$ Some scholars (Kubát 2013; Kocmánek 2006) have argued in favour of such a change, while others (Jelínek 2013) have been critical of the idea. Still others prefer to keep the existing proportional system, but with the proviso of awarding a substantial bonus to the winning party (Novák 2013). Supporters of electoral reform advocating a majority system see the benefits in easier government formation, a clear definition of opposition and the curtailment of populist and/or isolated parties that sit in the Chamber of Deputies and complicate the formation of working government coalitions.

Generally, when evaluating majority systems, Czech scholarly contributions (see also Lebeda 2000; Šedo 2014), apart from modelling various variants of proportional systems, fail to proceed beyond generic conclusions based on experiences from abroad. This paper therefore seeks to sketch the contours of a possible majoritarian reform. I specifically aim to provide an example of what the results of the elections to the chamber might look like under a first-past-the-post and a two-round system, and point out both the possible benefits and the drawbacks of such systems, should either be used in the first-order-elections to the Chamber of Deputies.

This article thus has a limited purpose and ambition. It does not aim to simulate the outcome of elections under a different electoral system, since it is not possible to predict the psychological effects of such a change on either voters or parties. Instead, I use the actual electoral results to demonstrate the mechanical effects of the proposed electoral reform in the Czech Republic. This should allow the reader to form an idea about what the consequences of a change would be, which is necessary to evaluate the benefits and consequences for Czech democracy of switching the system. The key issues in this sense are (a) whether clearer majorities in the chamber could be expected following the change, (b) the effect on populist parties that have emerged over the six years since 2010, and (c) the position of smaller parties under the alternative systems, particularly that of the Communist Party of Bohemia and Moravia (Komunistické strana Cech a Moravy, KSČM), which

\footnotetext{
4 'We want a majority electoral system. There will be no more excuses,' said the leader of the ANO movement, Andrej Babiš, interviewed on Václav Moravec's regular programme on Rádio Impuls (recording and transcript available at http://www.impuls.cz/clanky/2013/10/video-andrej-babischceme-vetsinovy-volebni-system/).
} 
is considered anti-system by most authors (Kubát 2013; Cabada and Šanc 2005; Hloušek and Kopeček 2010).

I am aware that modelling electoral outcomes to evaluate the effects of electoral reform is controversial and has many limitations. ${ }^{5}$ This is why I explain my reasoning in more detail below, after a brief overview of the current electoral system and its history and an equally brief discussion of the characteristics of the majoritarian system. This article purposely does not deal with the politics of electoral reform and the normative aspects of the proposed changes in detail. Such discussions (in Czech) can be found in the original conference proceedings (Balík et al. 2013).

\section{Electoral system for the Chamber of Deputies and its changes}

Article 18 of the Czech Constitution (Act No. 1/1993 Coll.) states that a proportional system is used to elect the Chamber of Deputies, but does not specify details. It also stipulates a majority system for elections to the upper chamber, the Senate, similarly without giving any further details. These are set in Act No. 247/1995 Coll., which has been amended multiple times. Electoral reform was first seriously discussed in 1998, when, following an agreement with the opposition ODS, the winner of the elections, the Social Democratic Party (Ceská strana sociálnè demokratická, ČSSD), created a minority cabinet. An integral part of the agreement that determined the position of the government was the condition that there would be electoral reform, with the aims of facilitating government formation for the electorally more successful parties and strengthening the government's position in the Czech political system. However, given the make-up of the Senate at the time, an amendment to the Constitution was not viable, and hence a change in electoral law to the effect of preserving the proportional system, but making it more majoritarian, seemed a workable solution. Following lengthy negotiations, a reform was devised that would divide the country into 35 constituencies, increase the threshold for coalitions, and introduce a modified D'Hondt divisor for converting votes into seats. ${ }^{6}$ However, in its ruling No.64/2001 Coll., the Constitutional Court annulled the reform without a vote ever being held according to the new rules. The court's ruling forced the political leaders to come up with a quick amendment, which continues to be in force today. The Czech Republic is divided into 14 constituencies, whose boundaries correspond to those of the

\footnotetext{
5 There is a large body of literature discussing what kinds of factors, apart from and including the mechanical effects of the electoral system, influence electoral outcomes and subsequently the whole party system (such as Duverger 1954; Rae 1967; Lipset and Rokkan 1967; Sartori 1968; Downs 1957; Riker 1982; Lijphart 1990; Lijphart 1994; Cox 1997).

${ }^{6}$ The divisor started with the value of 1.42 and was named the 'Koudelka divisor' after its proponent Zdeněk Koudelka (see e.g. Koudelka 2000; Kostelecký 2004).
} 
country's self-governing regions, and the classic D'Hondt method is used to transform votes into seats.

In mid-2006, there was another unexpected election result, and the allocation of seats in the chamber precluded the formation of a workable majority government. Thus, in subsequent years, an electoral reform was again on the table. The aim was not so much to push smaller parties into the background as it was to preserve (or increase) proportionality, with a bonus awarded to the winning party. This was not at the expense of smaller parties, which were now potential coalition partners, but rather at the expense of the second most successful party (Šedo 2009b). With the fall of the government in March 2009, the proposal never got past its early-draft stage, and no serious electoral reform has been put on the government's agenda since. Scholars, however, have not abandoned the issue, and in autumn 2012 the above-mentioned conference entitled 'Is a majority electoral system suitable for the Czech Chamber of Deputies?' took place, at which various options were analysed. Beyond earlier proposals that addressed purely technical matters of altering proportional representation, the principles of majority electoral systems were also discussed, and this paper follows upon these discussions.

\section{Why think this way: justifying the author's intention}

There have already been several studies of Czech electoral reform that considered changes in the method for converting votes into seats whilst preserving proportional representation. Since 2002 there have been multiple articles discussing potential reform, but they all envisaged a list-proportional system (Šedo 2009b; Lebeda 2004). These papers discussed potential election results under alternative ways of transforming votes into seats, and assessed various options in terms of their ability to produce a majority in the Chamber of Deputies, as well as other aspects. In doing so they assumed that voters' decision-making would not be affected by electoral-law amendments modifying the electoral formula, constituency sizes, etc.

I make the same assumption in my models, which consider the hypothetical introduction of a majority system. In doing so I also draw among others on the French experience where the electoral system has been modified multiple times over the last century, using both majority and proportional elements. During the first half of the twentieth century, deputies to the National Assembly obtained their legitimacy on the basis of a two-round majority system whose limiting effects were minimal. Immediately after 1945, a proportional representation system applied, which was soon replaced by other systems. In 1958 a two-round majority system was introduced, in which the second round was gradually closed to candidates of political parties that failed to poll $5 \%$, later $10 \%$ and eventually $12.5 \%$ of all registered voters. There were other subsequent changes: in 1986 a proportional electoral system was introduced and then swiftly amended after coming into force. In 1988, voting reverted to majority rules. However, during all this time there has 
never been a one-off, substantial change in the patterns of how regions vote, and the départements that have long supported the left and the liberals, or, by contrast, the right and the conservatives, tend not to switch their allegiances (Lacoste 1986).

Until 2010, local elections in municipalities of up to 20,000 inhabitants in Poland were held according to a proportional system. a majority electoral system was adopted in 2014 (except for large cities which continue to vote under a proportional system). a study describing the side effects of the change in terms of fragmentation and change in voters' strategies has concluded that the latter have not been substantially affected (Gendzwiłł and Zółtak 2016).

Whereas in a proportional electoral system the method for converting votes into seats is given much attention, in a majority system the demarcation of constituencies comes to the fore (not that this aspect would be unimportant in a proportional system, but it is merely one of its four fundamental characteristics, along with the electoral divisor, threshold and number of seats per constituency; cf. Lebeda 2001). As long as equality of suffrage is an objective, the size of constituencies and especially the delimitation of their boundaries are crucial. The fundamental principles of elections, as stipulated in the Czech Constitution and international documents, call for universal, direct, equal, free and secret suffrage. There are, however, certain risks attached to the establishment of constituencies, the most important being malapportionment ${ }^{7}$ and the other gerrymandering. ${ }^{8}$

Having taken all this into account, I believe that recalculating existing electoral results under different electoral systems can provide valuable insights into the

\footnotetext{
7 Malapportionment describes a situation where seats are unequally allocated to constituencies, giving different weights to individual votes. Such a situation can arise from an administrative measure, creating more and less populous constituencies. a good example would be a higher number of constituencies (recalculated per voter) in the capital at the expense of peripheral areas. Such a situation may arise through inactivity, when the population size in cities and the countryside changes due to migration and this trend is not reflected in corresponding changes to constituency boundaries (see e.g. Griffith 1907, Dixon 1968, Katz 1998, Rush 1993). In Europe, discrepancies of around $10 \%$ are considered acceptable, whereas a $15 \%$ discrepancy usually demands action. This is largely the practice, although the Constitutional Council in France has allowed a higher, $20 \%$, difference to remain (Antoš 2013: 140). In the Czech Republic, the Act No. 247/1995 Coll. stipulates that the boundaries of Senate constituencies are amended when the difference reaches $15 \%$.

${ }^{8}$ Gerrymandering is an intentional manipulation of constituencies aiming to give one political party an electoral majority in a large number of districts while concentrating the voting strength of the opposition in as few districts as possible favouring a specific group of candidates (see e.g. Gerrymandering n.d.). The term originated in the USA in the early nineteenth century. In essence, it describes a situation where the electoral support for a candidate is scattered across multiple constituencies, or, by contrast, the votes for a candidate are concentrated into a single constituency. a clear example is provided by a change of boundaries of a constituency where an ethnic minority, or the electorate of an opposition candidate, are strong. a good preventive measure is to observe the country's administrative territorial units and the principle of geographical contiguity. The question then is who should be making the changes. Ideally, it should be a body with parity representation of those contesting elections and the judiciary (for more detail see e.g. Shapiro 1984].
} 
(possible) effects of electoral reform. Of course, any conclusions drawn from such models are only tentative and should be treated as such. To give a concrete example, I will choose two types of majority system. One is the classic first-past-the-post system, well known in the Anglo-Saxon world and used among European countries solely in Britain. There are two main reasons for selecting this system for study: First, it is easy to model and hence to show which party would obtain the most votes in the proposed constituencies; and second, this was the model publicly advocated by ODS politicians prior to 2013. The other system is a two-round system which follows the rules presently in force for elections to the upper chamber of the Czech Parliament, the Senate.

Let me finally add a couple of words on constituencies. Under a majority system, the design of constituencies is key, and perhaps even more important than actual voting by the electorate. The territory of the Czech Republic would be divided into 200 constituencies, i.e. the same number of units as there presently are MPs in the lower chamber. In order for all votes to have approximately the same weight, the constituencies should be about the same size in terms of the number of registered voters. A similar rule would apply as the one in force for Senate elections, where a constituency boundary is amended if the difference (growth or reduction) in its electorate reaches $15 \%$. For our model of elections to the Chamber of Deputies, the constituencies would each have about 42,000 voters ${ }^{9}$ - a figure based on the total number of electors included on the register, divided by 200 (the number of seats). Our second rule is to respect as much as possible the country's administrative boundaries, so that those which have been in place are observed. Thus, no constituency will cross regional boundaries (as is the case in Senate constituencies); and the country's administrative structure as applies to collecting taxes, duties etc. will be taken into consideration to the greatest possible extent. The administrative districts of municipalities with extended powers, or, in relevant cases, those with commissioned local authority, will serve as the basis for our constituencies. Designing constituencies under these rules is not easy, but it is possible. Strict adherence to the rules would prevent any manipulation of constituency boundaries that aimed to influence election results.

\section{Effects of electoral reform ${ }^{10}$}

Electoral reform is an often-studied topic and published works as well as other sources tell us that there is no universally valid and suitable procedure to achieve it. Since 1990 we have witnessed several instances of substantial change in electoral

\footnotetext{
9 The calculation for 2013 (total number of voters/200) comes up with an average constituency size of 42,122 voters.

${ }^{10}$ This section provides only a very brief introduction; for a more detailed and informed discussion see any of the volumes mentioned here or Dunleavy-Margetts (1995).
} 
systems, both in established democracies and in countries undergoing transformation, most of them in Central and Eastern Europe. The former group includes Italy, Japan and New Zealand, with both proportional (Italy) and majority (New Zealand) systems being adjusted. In both these cases, the reform did not result in a different majority or proportional system being adopted; rather, both countries adopted a system of mixed-member proportional representation, somewhere between a proportional and a majority system.

These and other examples of reform have been described in an important volume edited by Matthew Shugart and Martin Wattenberg (2003a). The contributors observed mixed systems for two or three electoral terms, focusing on these systems' suitability for overcoming the shortcomings of previous systems, while preserving stability. Their main conclusion was that, to be successful, the reformed system should (1) offer a clear government-opposition choice, one that could be endorsed by a majority of voters (the interparty dimension), and (2) encourage parties and politicians to campaign on the basis of broad collective policy programmes (the intraparty dimension) (Shugart 2003: 29).

Systematic analyses of electoral systems can be found in the volume edited by Michael Gallagher and Paul Mitchell (2005) which, apart from comparative chapters, incorporates case studies of individual countries grouped by the type of electoral system, including some of those mentioned here. While not focusing specifically on electoral reform as such, the volume deals with the issue extensively, drawing attention, among other things, to the barriers to change, such as incumbent parties, institutional barriers, and the electorate itself. Even if proponents of electoral reform manage to overcome these barriers, they can be disappointed with the results of electoral reform. a study edited by Bowler and Donovan (2013) shows that institutional effects of electoral change are influenced by a number of other factors, including economic and socio-political developments, attitudes and behaviour of both parties and the electorate, and so on.

Another important work edited by André Blais (2008) covers electoral reform in countries using the first-past-the-post system. The authors describe the arguments of actors as to whether or not to change the existing rules. They conclude that changing an electoral system is no easy matter. Finally, Alan Renwick (2010) studied electoral reforms over the long term in multiple countries. He analysed the countries that have already been studied by others and added France, where over the past century or so the electoral system has been modified several times.

Of all the cases covered in these volumes, post-1993 Italy comes closest to the reform of the Czech parliamentary elections considered in this paper. In Italy, a strongly proportional system was changed to a mixed one, with $75 \%$ of the seats elected via the majority method. One chapter in Shugart and Wattenberg (2003) describes the unexpected effects of the Italian reform. Since 1993 the party system has not yet become stabilised; rather, the opposite is true, and the index of the effective number of parties (a measure of party competition) reached a historical 
maximum after the reform (D'Alimonte 2003: 326). ${ }^{11}$ Political parties entering into election coalitions campaigned together, but this unity was short-lived and has not created bipartism (D'Alimonte and Bartolini 2002).

\section{Recalculated election results}

\section{a. First-past-the-post system (FPTP)}

Czech politicians (Martin Kuba, Petr Sokol) as well as scholars (Kocmánek 2006) have argued in favour of a first-past-the-post system in the Czech Republic. This electoral system has long been primarily associated with the United Kingdom, where it has been securing legitimacy for government for more than a century, and also with India, the most populous democracy in the world. Though in use in 47 countries, which account for $43.5 \%$ of the world's population (Reynolds et al. 2005), it is often subjected to attempts at electoral reform. ${ }^{12}$ Most of the countries using the FPTP system are former British imperial territories, such as Canada, India, Bangladesh, and African countries. No country in Continental Europe uses this system, and hence the idea of introducing FPTP in the Czech Republic runs counter to the established trends, effectively proposing to introduce a 'foreign' element to European practice. There are also those who say that FPTP will fall into disuse (ibid.). The FPTP system has four fundamental characteristics: It is a single-round election of one candidate in a single-member constituency, with whoever wins the most votes being declared the winner.

The system is simple and intelligible to the electorate in terms of what happens with their votes. There is no need for a complicated conversion of votes into seats of the kind required in proportional systems - a procedure often opaque even to politicians themselves. Voters thus do not feel deceived, as they might under, say, a seat-allocation method that uses multiple rounds of counting, which has various side effects. ${ }^{13}$ The chief expected benefit of the FPTP system is that it offers to voters a clear choice between two alternatives and significantly limits the chances of third and new parties. It can be thus expected that the system will offer two viable options, one left-wing and the other right-wing. Hence it should produce a single party government, though that is not necessarily always the case - one such example was the UK between 2010 and 2015.

Let me now compare Czech parties and their electoral results. Our first example is based on the most recent elections to the Chamber of Deputies in 2013,

11 The effective number of parliamentary parties increased from 3.1 in 1976 to 4.1 in 1987 and to 7.0 in 1994.

12 a good example of a country that abandoned the FPTP system is New Zealand, where a mixed member proportional system replaced the FPTP in 1993 (see Vowles 2005).

${ }^{13}$ Here i mention the electoral system used for local elections in the Czech Republic. It is not easy to explain to failed candidates why they have not been awarded seats despite having polled more votes than their opponents who did get the mandate. 
when seven parties crossed the $5 \%$ threshold and the winner took a mere 50 seats. This was the weakest showing of a winning party in the history of the Czech Chamber of Deputies. There are also parties in the chamber that have relatively small seat shares, about 15 each.

If we recalculate under the FPTP system the votes cast according to the constituencies we have designed, we can see that the winner of the election, the ČSSD, would be awarded 112 seats. This means a more than a $100 \%$ increase, a result that would be sufficient for the ČSSD to form a majority government. The results of other parties are also interesting: ANO would place second, but the difference in seats obtained, compared to both the present system and what the ČSSD would receive, would be minimal. TOP09 would get an almost negligible gain of two seats. All other parties would receive either far fewer seats (KSČM) or none at all (ODS, KDU-ČSL and Dawn).

Table 1: Model calculation of election results for 2013

\begin{tabular}{|c|c|c|c|c|c|c|c|}
\hline 2013 & ČSSD & ANO & KSČM & TOP09 & ODS & Dawn & KDU-ČSL \\
\hline Result (\%) & 20.45 & 18.65 & 14.91 & 11.99 & 7.72 & 6.88 & 6.78 \\
\hline Actual & 50 & 47 & 33 & 26 & 16 & 14 & 14 \\
\hline FPTP & 112 & 54 & 6 & 28 & 0 & 0 & 0 \\
\hline
\end{tabular}

Source: Own calculation based on www.volby.cz.

The model calculation for 2010 shows an even greater incidence of majoritarian elements. The winner of the election, the ČSSD, would obtain 122 seats, while other parties would receive fewer seats than under the present system. The ODS would lose 4, TOP09, hitherto in government, 12. KSCM and the populist VV party would not win a single seat. Thus there would be in the lower chamber a clear government majority and two programmatically close opposition parties.

Table 2: Model calculation of election results for 2010

\begin{tabular}{|c|c|c|c|c|c|}
\hline 2010 & ČSSD & ODS & TOP09 & KSČM & VV \\
\hline Result (\%) & 22.08 & 20.22 & 16.70 & 11.27 & 10.88 \\
\hline Actual & 56 & 53 & 41 & 26 & 24 \\
\hline FPTP & 122 & 49 & 29 & 0 & 0 \\
\hline
\end{tabular}

Source: Own calculation based on www.volby.cz. 
The last example compares the actual and recalculated results of the 2006 election, whose results made finding a workable majority in the chamber proved particularly difficult. The ODS as the winner was unable to form a coalition government. There followed a short period of its minority cabinet, which failed to win the chamber's confidence. The ODS chair, re-appointed as PM, then proposed a coalition government which won confidence, thanks to two social-democratic MPs leaving the chamber before the vote. This shaky majority spurred electoral reform, which was however never put into practice because the government fell in early 2009. The calculation shows that under the FPTP system the ODS would get 31 more seats and would thus command a comfortable majority of 112 MPs. The opposition (ČSSD) would have 88 seats; no other parties would be present in the chamber.

Table 3: Model calculation of election results for 2006

\begin{tabular}{|c|c|c|c|c|c|}
\hline 2006 & ODS & ČSSD & KSČM & KDU-ČSL & SZ \\
\hline Result (\%) & 35.58 & 32.32 & 12.81 & 7.22 & 6.29 \\
\hline Actual & 81 & 74 & 26 & 13 & 6 \\
\hline FPTP & 112 & 88 & 0 & 0 & 0 \\
\hline
\end{tabular}

Source: Own calculation based on www.volby.cz.

All of the above shows that if FPTP were introduced in the Czech Republic, the winner of elections would get an absolute (101) or even a qualified (three-fifths, i.e. 120) majority in the chamber, the latter being necessary to change the constitution. This would be true of ODS (2006) and CSSD (2010 and 2013), parties which won but did not always get the chance to form a government and fill the post of prime minister. Second, the KSČM, an extreme party which the other parties have decided to exclude from forming national-level governments, would be unable to win as many seats as it does under the present system. The KDU-ČSL and the Green Party (Strana zelených, SZ) as the smallest successful in the 2006 election would also lose out. The third expected characteristic would be the presence of a distinct and homogeneous opposition.

Beyond the allocation of seats, it is interesting to observe how these would be distributed regionally. Figure 1 shows the changes the model would bring for the 2013 election. TOP09 would become a party with MPs elected in Prague and some adjacent constituencies in the Central Bohemia region. The six MPs for KSČM would be all elected in the Ústí nad Labem region. ANO would win no seats in the South Moravia, Moravia-Silesia or Vysočina regions; whereas ČSSD would fail utterly in Prague and the Liberec region. 
Figure 1: Model of election results under the FPTP system, 2013

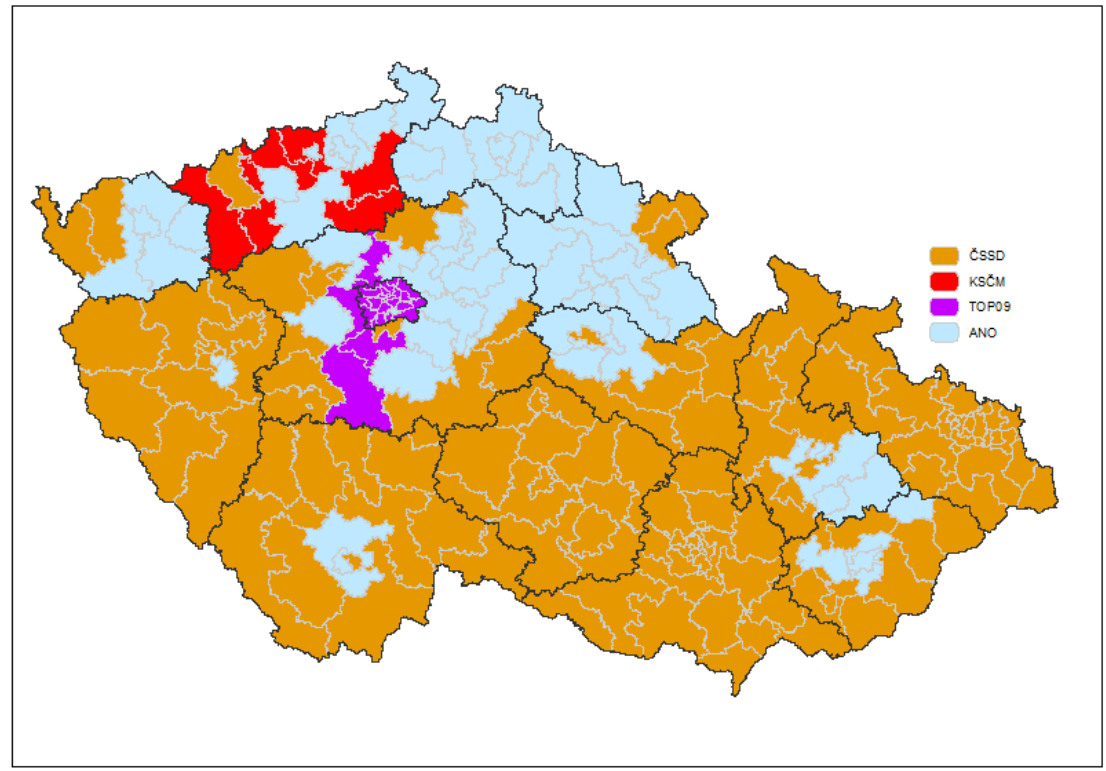

Source: Own map/www.volby.cz.

Figure 2: Model of election results under the FPTP system, 2010

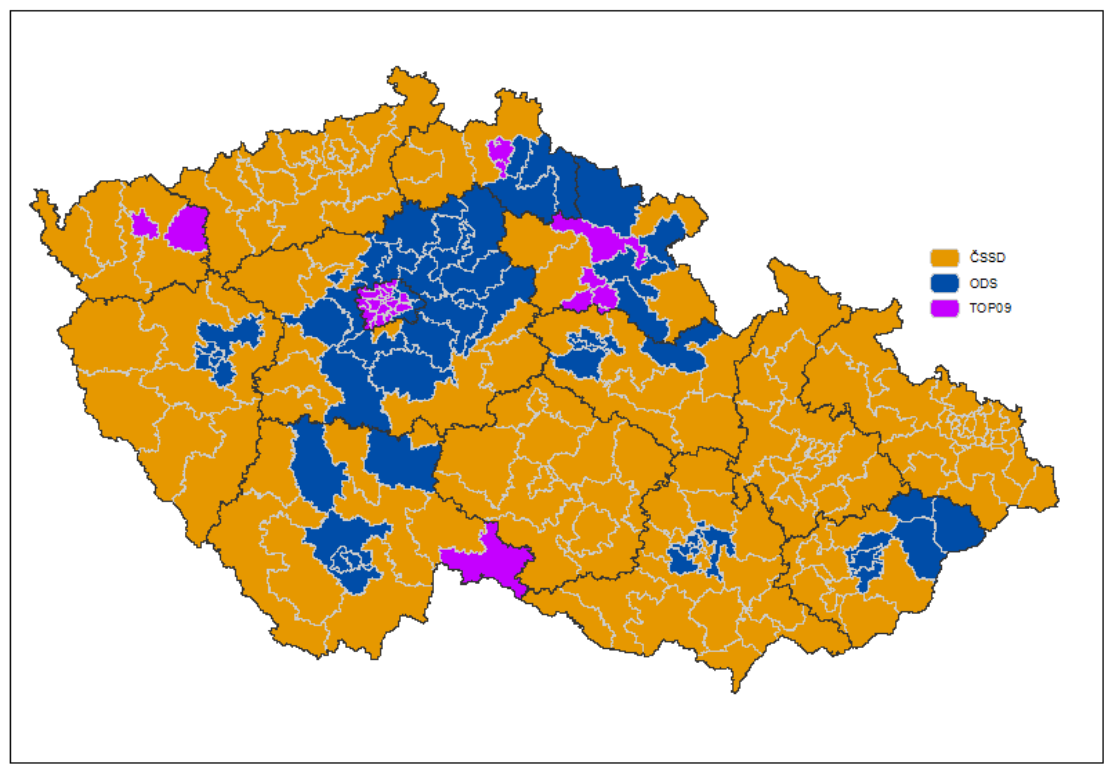

Source: Own map/www.volby.cz. 
Similar regional discrepancies in seat allocation can also be observed in Figure 2 for the 2010 elections. The ČSSD would get no seats in Prague, but would win all constituencies in Moravia-Silesia and Ústí nad Labem regions. ODS and TOP09 would get most of their MPs from Prague, Central Bohemia and five further constituencies in East Bohemia. The ODS would also get some MPs in the South Moravia and Zlín regions, but their numbers would be limited.

The model for 2006 shows clear regional polarisation. ODS would obtain seats primarily in Prague and the Central Bohemia, South Bohemia and Hradec Králové regions. By contrast, in the Moravia-Silesia region where ČSSD would score a clear victory, ODS would be eliminated - as the ČSSD would be in Prague.

\section{Figure 3: Model of election results under the FPTP system, 2006}

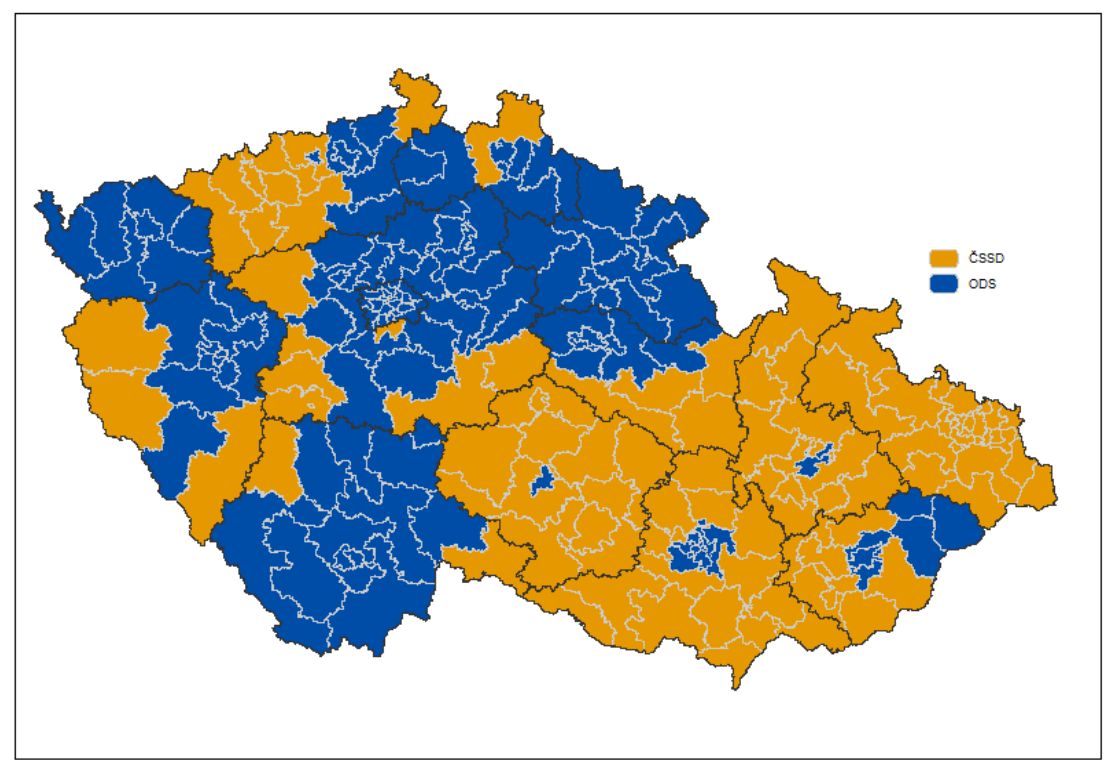

Source: Own map/www.volby.cz.

An evaluation of disproportionality should be an integral part of assessing electoral systems and their effects. Here I show the potential impact of majoritarian reform using the Loosemore-Hanby index. ${ }^{14}$ Should the FPTP system be adopted, disproportionality would increase: from 12.62 to 45.91 for 2013, from 18.85 to 43.20 for 2010 and from 9.99 to 32.30 for 2006. This clearly shows the other face of adopting the FPTP system.

\footnotetext{
14 The Loosemore-Hanby index measures the disproportionality of electoral systems. It computes the absolute difference between votes cast and seats obtained using a formula (Grilli di Cortona et al. 1999).
} 
Table 4: Comparison of disproportionality under the present and the FPTP systems

\begin{tabular}{|c|c|c|}
\hline Elections & Actual system & FPTP \\
\hline 2013 & 12.62 & 45.91 \\
\hline 2010 & 18.85 & 43.20 \\
\hline 2006 & 9.99 & 32.30 \\
\hline
\end{tabular}

Source: Own calculation based on www.volby.cz.

\section{b. Two-round majority system: the Senate model applied to the Chamber of Deputies ${ }^{15}$}

Since its inception in 1996, the Senate as the upper chamber of the Czech Parliament has been voted in on the basis of a two-round majority electoral system, the second round (run-off) being held if no candidate polls an absolute majority of votes in the first round. There have been only nine instances of candidates winning an absolute majority in the first round, and since 2008 a run-off has always been held in every constituency. In the recalculation of the results of the three most recent elections to the Chamber of Deputies, no candidate (political party) would win a constituency in the first round; hence a run-off would always take place. According to Giovanni Sartori, this system punishes ideological politics and rewards pragmatic politics (Sartori 1997).

France is one country in Europe which uses this method to elect its legislature. Two-round voting has been in force there since the 1950s, while an experiment with proportional representation in 1986 was soon abandoned, thus confirming that the two-round majority system is a suitable way for granting legitimacy to MPs in the country. Unlike the method used to elect the Czech Senate, in France the second round is open to more than two candidates: all who poll more than $12.5 \%$ of the votes of all registered electors pass to the second round. In theory, therefore, a voter might encounter more than three candidates in the second round, but this has not occurred for a long time. ${ }^{16}$ Also the advancement of more than two candidates to the second round has been quite infrequent; though when such cases occurred, they were closely watched. ${ }^{17}$ However, these multi-party second rounds have not

\footnotetext{
${ }^{15}$ More detailed results of each party in the second round are provided in the Appendices.

${ }^{16}$ Out of the total of 577 constituencies, more than two candidates progressed in 11 constituencies in 2002, in one constituency in 2007 and in 44 constituencies in 2012 (Le Ministère de l'intérieur n.d.).

${ }^{17}$ Classic examples include National Front (FN) candidates, who had been however unsuccessful in the run-off until 2012; or local politicians able to push national politicians into the background. In 2012, an independent left-wing candidate Olivier Falorni passed to the second round and subsequently won the seat, beating off Ségolene Royal, the Socialist Party (PS) candidate who had previously stood for election as the country's president. The centrist candidate F. Bayrou and the FN leader M. Le Pen have been also successful in this way.
} 
fundamentally disrupted the workings of the electoral system, or the resultant majority in the National Assembly.

It is important to note that under such a set-up the parties themselves might behave somewhat differently. In France, for instance, we have witnessed a number of coalitions in which ideologically close parties have been able to field a joint candidate or candidate list (see e.g. Elgie 2005). Whether such an effect would also be obtained in a post-reform Czech Republic is an open question. Given the recurrent practice in Senate elections, where two ideologically close parties who are in government together choose to field competing candidates, one may assume that parties would not be much inclined to create such coalitions.

A fundamental characteristic of a two-round electoral system is that voters vote repeatedly. Sartori (1997) described it as a system in which voters may freely express their preferences in the first round. Their freedom there is maximal, similar to that available in a proportional representation system. The first round serves as a selection - something like a primary election - producing the group of candidates that enjoy the greatest support of the electorate. In the second round, the voters are often pushed by the majority will towards their second or third preference. Crucial for success, therefore, is to increase one's share of the vote between the first and second rounds. The votes of those who opted for candidates that were eliminated in the first round are of decisive importance for the result of the second (final) round. According to Sartori, the system thus produces flexible parties (ones able to accommodate both majority and proportional rules) and calms politics down. Parties described by Sartori as extremist, extreme or isolated tend to lose out under this system.

In what follows, a variant of a two-round system is applied to the political environment of the Czech Republic. As mentioned above, it is the method used to elect the upper chamber of the Czech Parliament (the Senate). If no candidate wins absolute majority in the first round, the top two candidates contest the second. This model has been used in the Czech lands for more than a hundred years.

Senate election results between 1996 and 2008 (Navrátil 2010) show that candidates of different parties vary in their ability to win. Winning a seat in the first round is a possibility, but in actuality this has only happened in nine cases out of the about 330 total, making the advancement to the second round much more likely. ODS candidates are generally among those who do pass to the second round, with only the ČSSD candidates being able to compete in this regard. Small parties were successful in 1998 and 2000 when they worked together in the Coalition of Four (Ctyrkoalice, 4K). The lead enjoyed by ODS candidates after the first round however subsequently results in a certain isolation, since the high number of candidates advancing to the second round does not translate to the number of seats won. The candidates of other parties do better in the second round, with the exception of KSČM, whose candidates are even more isolated than those of ODS. An interesting group are politicians who are elected either without party support or with backing 
by regional groupings of marginal national influence. Such candidates do also win seats, even if rarely. ${ }^{18}$ It needs to be noted that Senate elections are, in many respects, second-order elections. Accordingly, voter turnout is low and candidates opposing the government (or those from minor coalition parties) are more likely to win seats, especially if elections to the Senate are held at the mid-term point of a government's mandate. The tables and maps that follow are based on the application of the Senate electoral system to elections to the Chamber of Deputies. Parties' potential ability to win seats in the second round of voting is also noted, in accordance with Navrátil (2008).

\section{Table 5: Model calculation of election results for 2013 - numbers of candidates advancing to the second round}

\begin{tabular}{|c|c|c|c|c|c|c|c|}
\hline 2013 & ČSSD & ANO & KSČM & TOP09 & ODS & Dawn & KDU-ČSL \\
\hline Result (\%) & 20.45 & 18.65 & 14.91 & 11.99 & 7.72 & 6.88 & 6.78 \\
\hline Actual & 50 & 47 & 33 & 26 & 16 & 14 & 14 \\
\hline Passing & 156 & 150 & 49 & 39 & 2 & 0 & 4 \\
\hline
\end{tabular}

Source: Own calculation based on www.volby.cz.

Table 5 shows that, apart from Dawn, all parties currently in the chamber would get their candidates into the second round of a majority system. However, the number of passing candidates differs widely across parties. ĆSSD and ANO would each have 150 or more candidates in the second round, with ČSSD being slightly ahead. TOP09 and KSČM would have 49 and 39 candidates respectively advancing to the second round - both relatively large groups whose order of magnitude corresponds to the actual results under the present system. With the remaining parties, however, the discrepancy between actual results and the projected numbers of passing candidates under the two-round system is profound. The KDU-ČSL would get only 4 candidates in the second round and the ODS 2. Given such significant differences in the numbers of passing candidates, it makes sense to analyse the possible second round in greater detail and within a regional comparison. Especially for KDU-ČSL, the results in terms of the ability of party candidates to pass to the second round are interesting: the party would fare much worse under the modelled conditions than it presently does in Senate elections. In the elections to the upper chamber, the party is presently able not just to pass to the second round but also to win seats. ${ }^{19}$ In my model of the electoral system, a higher voter turnout is envisaged, because turnout for the Chamber of Deputies

18 Truly independent and non-party candidates elected have included Zdeněk Nytra (2016), Petr Skála (2006) and, in a by-election, Václav Fišer (1999).

19 As of 2017, the KDU-ČSL parliamentary party group in the Senate has 16 members (including non-partisans aligned with the party), accounting for almost $20 \%$ of the Senate. 
elections is about 20-30 percentage points higher than for the Senate elections. Thus, what matters for the party result is not just the votes it has managed to win, but also the number of votes polled by its competitors.

Figure 4 shows that electoral competition in individual regions would be shaped very differently. In Prague, TOP09 would advance to the second round in every constituency, facing ODS in two cases and ANO in the remaining ones. All other parties would be eliminated, and hence the votes that were actually cast for $\check{C} S S D, K S \check{C} M$ and KDU-ČSL candidates would, in theory, decide the second round. TOP09 would also advance in the Central Bohemia and Liberec regions, and, in one constituency per region, in the Hradec Králové and South Moravia regions. Everywhere else the party would be eliminated from the second round. C SSD, by contrast, would get its candidates to the second round in all regions except Prague, competing most often against ANO, KSČM, and, in the South Moravia and Zlín regions, against KDU-ČSL or TOP09. In the Liberec and Ústí nad Labem regions, the second round would be particularly interesting, with KSČM and ANO candidates facing each other in six constituencies. It would be pure speculation to predict the result of such a contest; still, I venture to argue that KSČM's ability to capitalise on its gains in the first round would turn out to be limited, and the party would probably find it more difficult to win seats than ANO.

Figure 4: Model of candidates passing to the second round in 2013

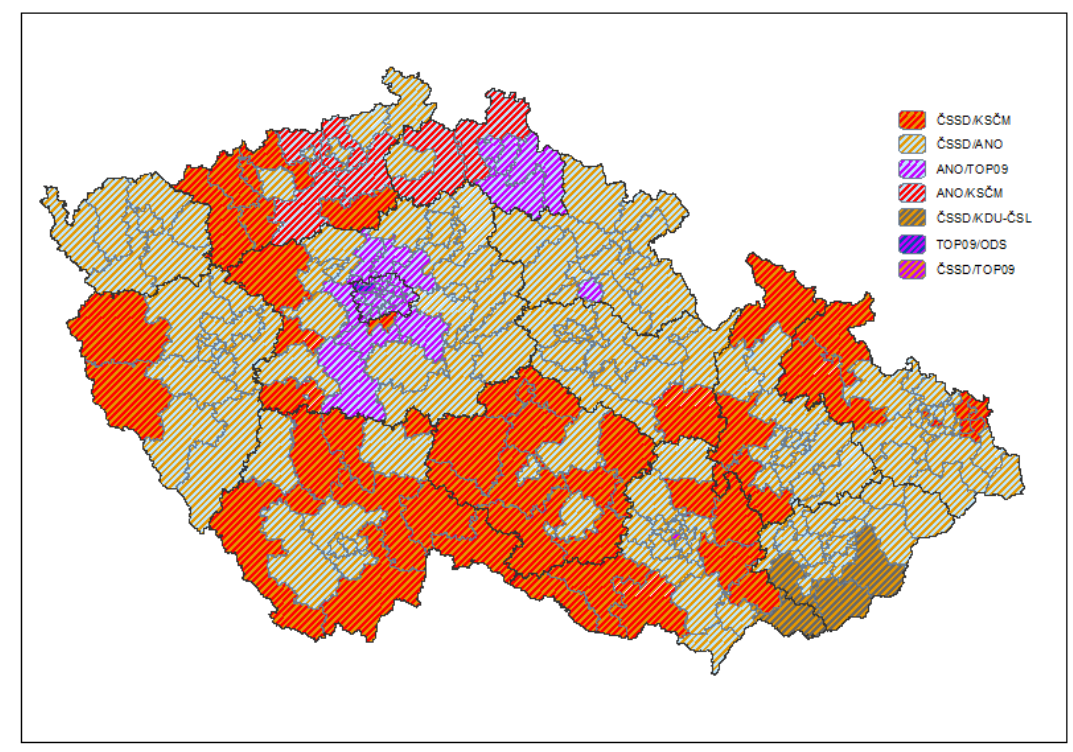

Source: Own map/www.volby.cz.

The numbers of candidates passing to the second round under the simulated 2010 election reveals that in this case the actual winner of the election would not 
be the party with the highest number of candidates in the second round. ODS, which placed second according to popular vote, would have most candidates advancing (171); by contrast, the ČSSD would contest the run-off in 151 constituencies. Fifty-two TOP09 candidates would enter the second round. For the remaining two parties, the eliminating influence of this electoral system would be obvious: VV, whose support was spread equally across the country, would only have one candidate in the second round, while KSCM would have 17, most of them facing ČSSD candidates.

Table 6: Model calculation of election results for 2010 - numbers of candidates advancing to the second round

\begin{tabular}{|c|c|c|c|c|c|}
\hline 2010 & ČSSD & ODS & TOP09 & KSČM & VV \\
\hline Result (\%) & 22.08 & 20.22 & 16.70 & 11.27 & 10.88 \\
\hline Actual & 56 & 53 & 41 & 26 & 24 \\
\hline Passing & 151 & 179 & 52 & 17 & 1 \\
\hline
\end{tabular}

Source: Own calculation based on www.volby.cz.

Figure 5: Model of candidates passing to the second round in 2010

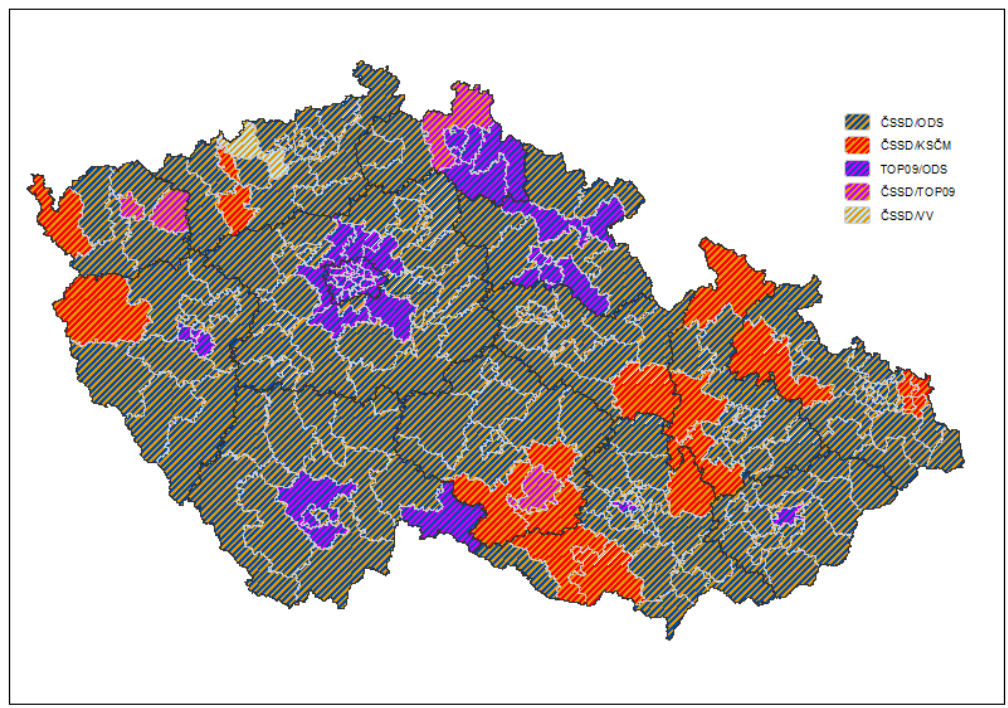

Source: Own map/www.volby.cz.

Figure 5 provides an instructive picture of how the second round of voting would look in 2010. As in 2013, there is a notable difference between Prague and the rest of the country. In Prague the contest would be held between ODS and TOP09 candidates. The situation would be similar in some regions, especially in or 
around large cities. In other regions the contest would be between ČSSD and ODS candidates.

Also of interest are constituencies where two leftist candidates (i.e. of ČSSD and KSČM) would pass to the second round. There would be one such constituency in each of the Plzeň, Karlovy Vary, Ústí nad Labem and Pardubice regions, and multiple cases in all regions located in Moravia, with the exception of the Zlin region. As might be expected, the greatest number of such constituencies would be found in Moravia-Silesia. In three regions we find one constituency with a contest between ČSSD and TOP09 candidates. One constituency in the Ústí nad Labem region would see a candidate of the VV party competing against a ČSSD candidate. To complete the picture I also provide Table 7 which shows the number of advancing candidates per party in 2006 - the year when establishing governmental majority in the lower chamber was particularly problematic.

Table 7: Model calculation of election results for 2006 - numbers of candidates advancing to the second round

\begin{tabular}{|c|c|c|c|c|c|}
\hline 2006 & ODS & ČSSD & KSČM & KDU-ČSL & SZ \\
\hline Result (\%) & 35.58 & 32.32 & 12.81 & 7.22 & 6.29 \\
\hline Actual & 81 & 74 & 26 & 13 & 6 \\
\hline Passing & 200 & 200 & 0 & 0 & 0 \\
\hline
\end{tabular}

Source: Own calculation based on www.volby.cz.

As captured in Figure 6, this clearly shows that the second round would be a contest between ODS and ČSSD candidates only. Who would ultimately win is a big unknown, since low predictability is one of the better-known attributes of this electoral system. 
Figure 6: Model of candidates passing to the second round in 2006

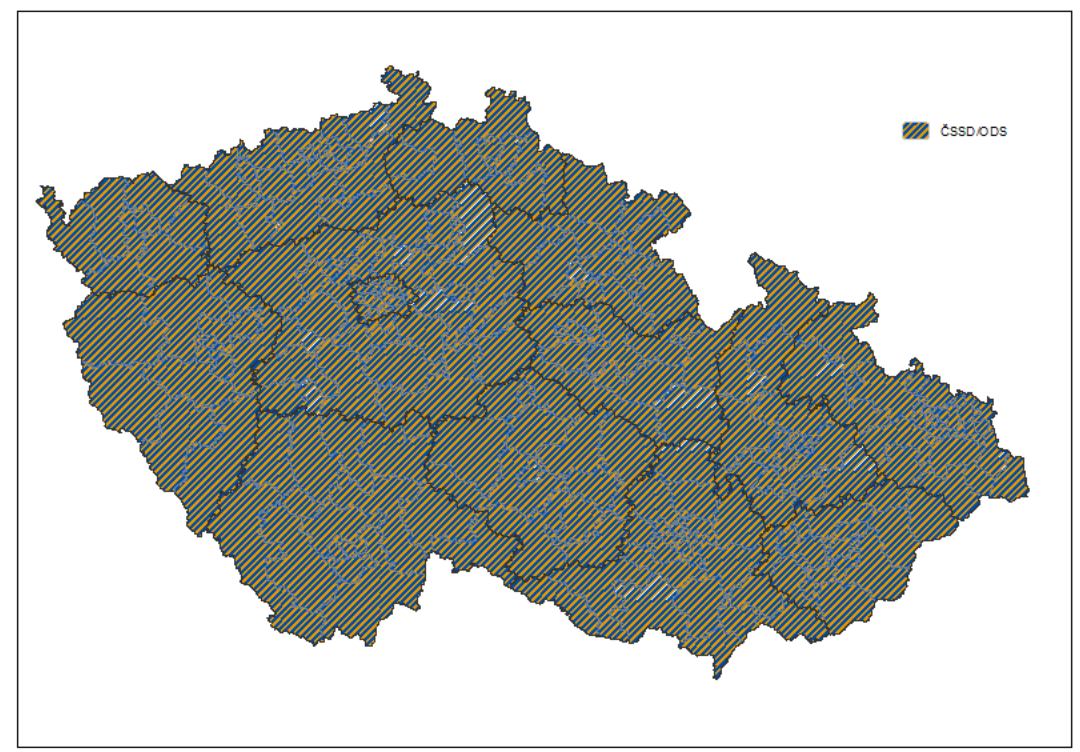

Source: Own map/www.volby.cz.

\section{Discussion}

In addition to the possible results of the electoral reform, which promise easier majorities in the Chamber of Deputies, one also needs to note the weaknesses, or, as the case may be, the risks inherent in the change. Beyond the very set-up of constituency boundaries and other circumstances that are technical and administrative in character, there are two related weaknesses. (1) The first is a fundamental change with regard to the threshold which parties have to reach in order to win seats, and which currently sits at at $5 \%$ nationwide. Removing this threshold might spur a disintegration of the party system, allowing people independent on the parties to win seats. While the level at which the electoral threshold is set is one of the fundamental characteristics of a proportional system, it is wholly absent in the majority system. The issues associated with the electoral threshold in the Czech Republic have been widely analysed both theoretically and empirically in scholarly literature (e.g. Lebeda 2001; Čaloud and Matušková 2006; Pink and Valterová 2010). a fundamental finding of this literature is that under the present $5 \%$ threshold, a party must poll about 230,000 votes nationally to be allocated seats. Within the individual constituencies (regions), one seat corresponds to roughly 20,000 votes (i.e. the quotient as determined by electoral formula). However, winning 20,000 votes does not necessarily mean that a seat will be allocated as the number of required votes differs across constituencies, depending on other circumstances - above all the number of unsuccessful candidate lists of 
parties contesting the election in a given constituency. In order to win seats, candidates must therefore clear several obstacles: First, they must win their party nomination, i.e. a place on the candidate list that actually stands a fair chance of being elected; and second, their party must then poll more than $5 \%$ of the vote nationally and win about 20,000 votes in the constituency (this assumes, of course, that the candidate is in the top position on her party's candidate list in the region).

The adoption of a majority system would lower this barrier substantially. a division of the Czech Republic into 200 constituencies would mean about 42,000 registered voters per constituency. Given that in the three most recent elections the turnout was about $60 \%,{ }^{20}$ one can assume that about 25,000 voters per constituency would show up on the election day. Under such circumstances an absolute majority of votes would be 12,501 or more. Obviously, one cannot predict what the exact turnout would be, but it is more likely to be a lower rather than a higher number. Compared to the present situation when a much greater number of votes are needed to win seats and these votes must be distributed spatially, the new system would place a much less stringent requirement on candidates in terms of their ability to attract votes. If a majority system is adopted, the requirements for winning a seat in the lower chamber will decrease substantially. We would thus have newly elected MPs whose electoral support was low, and in fact marginal from a nation-wide perspective. $^{21}$

When considering contemporary findings about the neighbour effect (Malcová 2011) and the population size of the average district town, one might well ask how a popular mayor, teacher, medical doctor or other local notables would fare in an election, assuming a context of non-developed local parties and a positive neighbour effect. The Chamber of Deputies could easily turn into a body of elected local politicians and regionally or locally known personalities whose support would not extent beyond the boundaries of their town.

(2) The second weakness, which is perhaps a direct consequence of the absence of the threshold in a majority system, would be increased fragmentation. To illustrate the issue I discuss the actual make-up of the Czech Senate which obtains its legitimacy from a two-round majority electoral system.

Table 12 details Senate elections to date. The proportion of senators elected as independents or representing regional parties ranged from a low of $12 \%$ in 1996

\footnotetext{
${ }^{20}$ Voter turnout was $59.48 \%$ in 2013, $62.60 \%$ in 2010 and $64.47 \%$ in 2006 . Thus it slowly decreases over time, but has been relatively homogeneous regionally.

21 As an anonymous reviewer of this article rightly pointed out, introduction of a majoritarian electoral system can reduce or block representation of marginal groups in the parliament. However, the opposite can be true as well, depending on the geographical distribution of such groups in the country (for example the German speaking population in South Tyrol). In the Czech case, no minority or regional parties have been represented in the Chamber of Deputies since 1996. Therefore, introducing a majoritarian system for the chamber is unlikely to have adverse effect on minority representation in this case.
} 
to more than $50 \%$ in 2014 and 2016. If such a high number of independents were to sit in the Chamber of Deputies, obvious issues would arise for the working and voting of parliamentary party groups, and the fragmented chamber would be at serious risk of political instability.

Table 8: Number of non-partisan senators (most of whom were elected with the support of a political party) or those elected on the lists of marginal parties

\begin{tabular}{|c|c|c|}
\hline $\begin{array}{c}\text { Year of } \\
\text { election }\end{array}$ & $\begin{array}{c}\text { Number of senators (27 in total are } \\
\text { elected at any term) }\end{array}$ & $\begin{array}{c}\text { Expressed as share of the } \\
\text { elected (\%) }\end{array}$ \\
\hline 1996 & 10 & 12 \\
\hline 1998 & 4 & 15 \\
\hline 2000 & 8 & 30 \\
\hline 2002 & 10 & 44 \\
\hline 2004 & 5 & 19 \\
\hline 2006 & 6 & 22 \\
\hline 2008 & 7 & 26 \\
\hline 2010 & 6 & 22 \\
\hline 2012 & 10 & 37 \\
\hline 2014 & 15 & 56 \\
\hline 2016 & 16 & 59 \\
\hline
\end{tabular}

Source: www.volby.cz.

\section{Conclusion}

This paper has described the possible outcomes of introducing a one-round and a two-round majority system for the election of the Czech Chamber of Deputies. Several differences are to be expected. According to my model calculations, if the FPTP system were adopted, the winning party would always command a clear majority in the Chamber. In all three cases considered, the victor would hold more than half of the seats in the chamber and there would be no need for coalition governments, as has been the case to date under the proportional system. In addition, there would be a clear-cut opposition, consisting of fewer parties than is presently the case. Would such an electoral reform be likely to boost or hinder the emergence and/or rise of populist parties? My models suggest that the latter option is more likely. Also KSČM would probably be seriously hit.

The model of a two-round system, with two best-placed candidates advancing into the run-off, shows similar tendencies. The party winning the popular vote would get its candidates into the second round in the greatest number of constituencies, and they would have to see off opponents not just from the other 
major party but also from smaller competitors such as KDU-ČSL and KSČM. Given how the second round of the system typically works, further predictions are difficult, but the present state of knowledge suggests that elimination of KSČM candidates in the second round would be expectable rather than not.

The adoption of a majority system would certainly bring many changes to the party system. One may conjecture that its introduction would create clear legislative majorities with sufficient legitimacy to form a government. My calculations indicate that fringe or isolated parties would probably be pushed further into the background. However, one also needs to note the risks involved in such a move. Bearing in mind the limitations of my calculations (as discussed above), these risks seem to outweigh the benefits. The chief risk is the disintegration of the party system and its replacement with an unstable and unpredictable atomised system, made up of non-partisans and independents with very narrow territorial legitimacy. This risk would be compounded by the lower election threshold. Combined with the habit of Czech politicians to combine multiple mandates (for example, that of an MP and a mayor), this might produce a significant risk factor.

\section{List of abbreviations}

\begin{tabular}{|c|c|c|c|}
\hline & Full name & Full name (English) & Note \\
\hline $\mathrm{ANO}$ & ANO 2011 & & $\begin{array}{l}\text { populist } \\
\text { party }\end{array}$ \\
\hline ČSSD & $\begin{array}{l}\text { Česká strana sociálně } \\
\text { demokratická }\end{array}$ & $\begin{array}{l}\text { Czech Social } \\
\text { Democratic Party }\end{array}$ & \\
\hline $\begin{array}{l}\text { KDU- } \\
\text { ČSL }\end{array}$ & $\begin{array}{l}\text { Křest’anskodemokratická unie } \\
\text { - Československá strana } \\
\text { lidová }\end{array}$ & $\begin{array}{l}\text { Christian and } \\
\text { Democratic Union - } \\
\text { Czechoslovak } \\
\text { People's Party }\end{array}$ & \\
\hline KSČM & $\begin{array}{l}\text { Komunistická strana Čech } \\
\text { a Moravy }\end{array}$ & $\begin{array}{l}\text { Communist Party of } \\
\text { Bohemia and Moravia }\end{array}$ & \\
\hline Dawn & Úsvit - Národní koalice & $\begin{array}{l}\text { Dawn - National } \\
\text { Coalition }\end{array}$ & $\begin{array}{l}\text { populist } \\
\text { party }\end{array}$ \\
\hline TOP09 & TOP09 & & liberal party \\
\hline ODS & $\begin{array}{l}\text { Občanská demokratická } \\
\text { strana }\end{array}$ & $\begin{array}{l}\text { Civic Democratic } \\
\text { Party }\end{array}$ & $\begin{array}{l}\text { conservative } \\
\text { party }\end{array}$ \\
\hline
\end{tabular}




\section{References}

Act of Law No. 1/1993 Coll., The Constitution of the Czech Republic.

Act of Law No. 247/1995 Coll., on elections to the Parliament of the Czech Republic.

Antoš, Marek (2013): "Malapportionment a gerrymandering: lze se jich při 200 volebních obvodech vyvarovat?" (Malapportionment and Gerrymandering: How to Avoid Them in the Case of 200 Constituencies) In: Stanislav Balík (ed.), Vètšinový systém pro snémovní volby? Ceské zkušenosti a debaty. Brno: CDK, 137-150.

Balík, Stanislav et al. (2013): Vètšinový systém pro snèmovni volby? Ceské queušenosti a debaty. (Majority Electoral System for Elections to Chamber of Deputies? Czech Experiences and Debates). Brno: CDK.

Balík, Stanislav and Hloušek, Vít (2016): “The Development and Transformation of the Czech Party System after 1989." Acta Politologica 8(2): 103-117

Blais, André (2008): To Keep it or To Change First Past the Post? The Politics of Electoral Reform. Oxford - New York: Oxford University Press.

Bowler, Shaun and Todd Donovan (2013): The Limits of Electoral Reform. New York: Oxford University Press.

Cabada, Ladislav and David Šanc (2005): Ceský stranický systém ve 20. století. (Czech Party System in the 20th Century.) Plzeň: Aleš Čeněk.

Čaloud, Dalibor and Anna Matušková (2006): "Kauza Pávek a Straka" (The Pavek and Straka Affair). In: Dalibor Čaloud, Tomáš Foltýn, Vlastimil Havlík and Anna Matušková (eds.), Volby do Poslanecké snémovny v roce 2006. Brno: CDK, 166-170.

Chytilek, Roman, Jakub Šedo, Tomáš Lebeda, and Dalibor Čaloud (2009): Volební systémy (Electoral systems). Praha: Portál.

Constitutional Court of the Czech Republic, Ruling No. 64/2001 Coll.

Cox, Gary (1997): Making Votes Count. Cambridge: Cambridge University Press.

Czech Republic Political System (n.d.). On-line (http://www.czech.cz/en/88070-czechrepublic-political-system).

D'Alimonte, Roberto (2003): "Mixed Electoral Rules, Partisan Realignment, and Party System Change in Italy." In: Matthew S. Shugart and Martin, P. Wattenberg (eds.), Mixed - Member Proportional Systems. The Best of Both Worlds? New York: Oxford University Press, 323-350.

D'Alimonte, Roberto and Bartolini, Stefano (2002): "La maggioranza ritrovata. La competizione nei collegi uninominali." In: Roberto D'Alimonte and Stefano Bartolini (eds.), Maggioritario Finalmente? La transiẓione elettorale 1994 - 2001. Bologna, Societá editrice il Mulino.

Deegan-Krause, Kevin (2010): “A Fragile Stability. The Institutional Roots of Low Party System Volatility in the Czech Republic, 1990-2009." Politologický ćasopis 2010(3): 227-241. Dixon, Robert (1968): Democratic Representation: Reapportionment in Law and Politics. New York: Oxford University Press.

Downs, Anthony (1957): An Economic Theory of Democracy. New York: Harper and Row. Dunleavy, Patrick and Margetts, Helen (1995): "Understanding the Dynamics of Electoral Reform." International Political Science Review 16 (1): 9-29. DOI: 10.1177/ 019251219501600102

Duverger, Maurice (1954): Political Parties: Their Organization and Activity in the Modern State.

New York: John Wiley. 
Elgie, Robert (2005): "France: Stacking the Deck." In: Michael Gallagher and Paul Mitchell (eds.), The Politics of Electoral Systems. New York: Oxford University Press, 119 - 136.

Gallagher Michael and Mitchell Paul (2005): The Politics of Electoral Systems. New York: Oxford University Press.

Gendzwiłł, Adam and Tomasz Zółtak (2016): What have single-member districts changed? An evidence from 2014 Polish local elections. Prague: ECPR.

Gerrymandering. (n.d.) In: Merriam-Webster's collegiate dictionary. Available at: (https://www.merriam-webster.com/dictionary/gerrymander\#h2).

Griffith, Elmer (1907): The Rise and Development of the Gerrymander. Chicago: Scott Foresman.

Grilli di Cortona, Pietro and Cecilia Manzi and Aline Pennisi and Federica and Bruno Simeone (1999): Evaluation and Optimization of Electoral Systems. SIAM.

Hloušek, Vít and Lubomír Kopeček (2010): Origin, Ideology and Transformation of Political Parties. East-Central and Western Europe Compared. Aldershot: Ashgate.

Impuls Rádio (30.10.2013): VIDEO: Andrej Babiš: Chceme vétšinový volebni systém! Available at: (http://www.impuls.cz/clanky/2013/10/video-andrej-babis-chceme-vetsinovyvolebni-system/).

Jelínek, Lukáš (2013): "Většinový volební system: Pohřebiště, nebo incubator stranické plurality?" In: Stanislav Balík (ed.), Vètšinový volebni system pro snèmovní volby? České qkeusenosti a debaty. Brno: CDK, 47-58.

Katz, Richard. S. (1998): "Malapportionment and Gerrymandering in Other Countries and Alternative Electoral Systems.” In: Mark E. Rush (ed.), Voting Rights and Redistricting in the United States. Westport, CT: Greenwood Press, 245-259.

Kocmánek, Jakub (2006): "Přísěpvěk k diskusi na téma většinový volební system při volbách do Poslanecké sněmovny parlamentu ČR.” In: Marek Antoš and Jan Wintr (eds.), Volebni systémy a volebni právo - české cesty v kontextu zabraničnich modelu. Praha: Právnická fakulta KU.

Kopecký Petr (2004): “The Czech Republic: Entrenching Proportional Representation." In: Joseph Colomer (ed.), The Handbook of Electoral System Choice. Palgrave Macmillan: London, 347-358.

Koudelka, Zdeněk (2000): “Změna volebního systému." Politologický časopis 7(1): 90-93.

Kubát, Michal (2013): Současná česká politika: co s neefektivním rey̌imem? (What to Do with Ineffective Regime?) Brno: Barrister \& Principal.

Lacoste, Yves (1986): Géopolitiques des régions françaises. Paris: Fayard.

Le Ministère de l'intérieur (n.d): Elections. On-line (https://www.interieur.gouv.fr/elections)

Lebeda, Tomáš (2000): "Possibilities for Modifying the System of Proportional Representation Aimed at Stabilizing the Executive In the Czech Republic." Czech Sociological Review 8(1): 49-68.

Lebeda, Tomáš (2001): "Přirozený práh poměrných systémů, teorie a realita" (Treshold in Proportional Representation System, Theory and Reality). Politologický ćasopis 8(2): 134 149.

Lebeda, Tomáš (2004): “Konečná podoba volebního systému pro Poslaneckou sněmovnu. Otazníky nad vynucenou úpravou z roku 2002.” (The Final Version of the Electoral System for the Chamber of Deputies. Questions about the Enforced Modification from 2002). In: Miroslav Novák and Tomáš Lebeda (eds.), Volební a stranické systémy: ČR $v$ mezinárodním srovnání. Dobrá Voda: Aleš Čeněk, 211-249. 
Lijphart, Arend (1994): Electoral Systems and Party Systems: a Study of Twenty-Seven Democracies, 1945-1990. New York: Oxford University Press.

Lijphart, Arend (1999): Patterns of Democracy: Government Forms and Performance in 36 Countries. New Haven: Yale University Press.

Lipset, Seymour Martin and Stein Rokkan (1967): Party Systems and Voter Alignments: Cross National Perspectives. New York: Free Press.

Navrátil, Vojtěch (2010): "Výsledky druhého kola senátních voleb 1996-2008: kdo, proti komu, odkud a jak" (Results of the Second Round of the Senatorial Elections 1996 1998: Who against Whom, Where and How). Stredoevropské politické studie 12(1), 79-98.

Novák, Miroslav (2013): "Je zapotřebí, abychom přešli k většinovým volbám do Poslanecké Sněmovny?” In: Stanislav Balík (ed.), Vètšinový volebni system pro snèmovní volby? Ceské qkušenosti a debaty. Brno: CDK, 119-136.

Pink, Michal and Aneta, Valterová (2010): "Volby do Poslanecké sněmovny České republiky 2010 a jejich alternativní výstupy" (Alternative Results to the Elections to the Chamber of Deputies in the Czech Republic 2010). Stredoevropské politické studie 12(2-3), 142-158.

Rae, Douglas (1967): The Political Consequences of Election Laws. New Haven: Yale UP

Renwick, Alan (2010): The Politics of Electoral Reform. Changing the Rules of Democracy. Cambridge: Cambridge University Press.

Reynolds, Andrew, Ben Reilly and Andrew Ellis (2005): Electoral System. Stockholm: International Idea.

Riker, William (1982): “The Two Party System and Duverger's Law." American Political Science Review 76(4): 753-766.

Rush, Mark E. (1993): Does Redistricting Make a Difference? Baltimore: Johns Hopkins UP.

Sartori, Giovanni (1968): "Political Development and Political Engineering." In: John D.

Montgomery and Albert Hirschman (eds.), Public Policy. Cambridge: Harvard UP

Sartori, Giovanni (1997): Comparative constitutional engineering: an inquiry into structures, incentives and outcomes. New York: NYU Press.

Šedo, Jakub (2009a): "Návrhy volební reformy a posun ve volebním inženýrství v České republice" (Proposals for Electoral Reform and the Shift in Electoral Engineering in the Czech Republic). Evropská volebni studia 4(1): 48-55.

Šedo, Jakub (2009b). "Reforma volebního systému v ČR - 20 let diskusî" (Electoral Reform in the Czech Republic - 20 Years of Discussion). Evropská volebni studia 4(2): 142-153.

Šedo, Jakub (2013): "Možnosti volebního inženýrství v ČR v kontextu voleb 2013." In: Vlastimil Havlík (ed.), Volby do Poslanecké snémovny 2013. Brno: Masarykova univerzita

Shapiro, Howard M. (1984): "Geometry and Geography: Racial Gerrymandering and the Voting Rights Act." The Yale Law Journal 94(1): 189-208.

Shugart, Matthew S. and Wattenberg, Martin, P. (eds.) (2003): Mixed-Member Proportional Systems: The Best of Both Worlds? New York: Oxford University Press.

Shugart, Matthew S. (2003): “'Extreme' Electoral Systems and the Appeal of the MixedMember Alternative." In: Mattew S. Shugart and Martin P. Wattenberg (eds.), MixedMember Proportional Systems: The Best of Both Worlds? New York: Oxford UP, 25-51

Vowles, Jack (2005): “New Zealand: The Consolidation of Reform?” In: Michael Gallagher and Paul Mitchell (eds.), The Politics of Electoral Systems. New York: Oxford University Press, 295-312. 


\section{Appendices}

Table A1. Projected combinations of parties contesting the second round of elections in 2013 according to regions

\begin{tabular}{|c|c|c|c|c|c|c|c|}
\hline 2013 & $\begin{array}{c}\text { TOP09/ } \\
\text { ANO }\end{array}$ & $\begin{array}{c}\text { ČSSD/ } \\
\text { ANO }\end{array}$ & $\begin{array}{l}\text { ČSSD/ } \\
\text { KSČM }\end{array}$ & $\begin{array}{l}\text { ANO/ } \\
\text { KSČM }\end{array}$ & $\begin{array}{l}\text { KDU- } \\
\text { ČSL/ } \\
\text { ČSSD }\end{array}$ & $\begin{array}{c}\text { TOP09/ } \\
\text { ČSSD }\end{array}$ & $\begin{array}{l}\text { ODS/ } \\
\text { TOP09 }\end{array}$ \\
\hline Prague & 23 & & & & & & 2 \\
\hline STČ & 7 & 15 & 2 & & & & \\
\hline JHČ & & 6 & 7 & & & & \\
\hline PLZ & & 9 & 2 & & & & \\
\hline KAR & & 5 & & & & & \\
\hline ÚST & & 5 & 5 & 4 & & & \\
\hline LIB & 5 & 1 & & 2 & & & \\
\hline KRA & 1 & 10 & & & & & \\
\hline PAR & & 9 & 1 & & & & \\
\hline VYS & & 3 & 7 & & & & \\
\hline $\mathrm{JIH}$ & & 14 & 7 & & 1 & 1 & \\
\hline OLO & & 9 & 3 & & & & \\
\hline MOR & & 13 & 9 & & & & \\
\hline ZLI & & 9 & & & 3 & & \\
\hline
\end{tabular}

Source: Own calculation based on www.volby.cz. 
Table A2: Projected combinations of parties contesting the second round of elections in 2010 according to regions

\begin{tabular}{|c|c|c|c|c|c|}
\hline 2010 & $\begin{array}{c}\text { TOP09/ } \\
\text { ODS }\end{array}$ & $\begin{array}{c}\text { ČSSD/ } \\
\text { ODS }\end{array}$ & $\begin{array}{l}\text { ČSSD/ } \\
\text { KSČM }\end{array}$ & $\begin{array}{c}\text { TOP09/ } \\
\text { ČSSD }\end{array}$ & $\begin{array}{c}\text { CSSD/ } \\
\text { VV }\end{array}$ \\
\hline Prague & 25 & & & & \\
\hline STC & 6 & 18 & & & \\
\hline JHČ & 3 & 10 & & & \\
\hline PLZ & 2 & 8 & 1 & & \\
\hline KAR & & 3 & 1 & 1 & \\
\hline ÚST & & 12 & 1 & & 1 \\
\hline LIB & 5 & 2 & & 1 & \\
\hline KRA & 5 & 6 & & & \\
\hline PAR & & 9 & 1 & & \\
\hline VYS & & 7 & 2 & 1 & \\
\hline JIH & 2 & 18 & 3 & & \\
\hline OLO & & 9 & 3 & & \\
\hline MOR & & 17 & 5 & & \\
\hline ZLI & 1 & 11 & & & \\
\hline
\end{tabular}

Source: Own calculation based on www.volby.cz. 
Figure A1. Regions in the Czech Republic

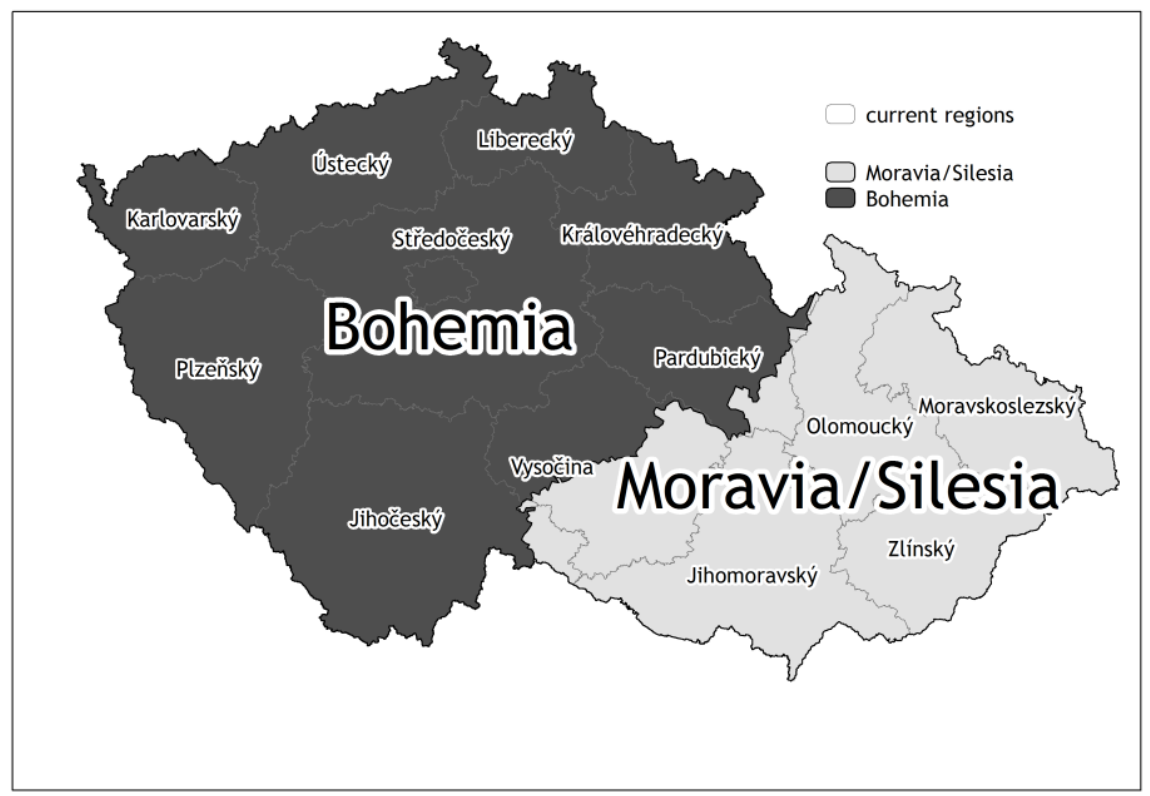

Source: Own map based on www.volby.cz.

Table A3: List of Czech Regions

\begin{tabular}{|c|c|c|}
\hline Czech name & English name & Abbreviation \\
\hline Praha & Prague & Prague \\
\hline Středočeský kraj & Central Bohemian region & STĆ \\
\hline Jihočeský kraj & South Bohemian region & JHČ \\
\hline Plzeňský kraj & Pilsen region & PLZ \\
\hline Karlovarský kraj & Karlovy Vary region & KAR \\
\hline Ústecký kraj & Ústí nad Labem region & ÚST \\
\hline Liberecký kraj & Liberec region & LIB \\
\hline Královéhradecký kraj & Hradec Králové region & KRA \\
\hline Pardubický kraj & Pardubice region & PAR \\
\hline Vysočina & Vysočina & VYS \\
\hline Jihomoravský kraj & South Moravian region & JIH \\
\hline Olomoucký kraj & Olomouc region & OLO \\
\hline Moravskoslezský kraj & Moravia-Silesia region & MOR \\
\hline Zlínský kraj & Zlín region & ZLI \\
\hline
\end{tabular}

Source: www.volby.cz 